\title{
Impact of Heat Stress on Cauliflower (Brassica Oleracea var. Botrytis): A Physiological Assessment
}

\author{
Saba Aleem ${ }^{1 *}$, Iram Sharif ${ }^{2}$, Mehvish Tahir ${ }^{3}$, Muhammad Najeebullah ${ }^{3}$, Ali Nawaz ${ }^{1}$, Muhammad Imran \\ Khan $^{1}$, Amina Batool ${ }^{1}$ and Waheed Arshad ${ }^{1}$
}

${ }^{1}$ Barani Agricultural Research Station, Fatehjang, Pakistan; ${ }^{2}$ Cotton Research Station, AARI, Faisalabad, Pakistan; ${ }^{3}$ Vegetable Research Institute, AARI, Faisalabad, Pakistan.

\begin{abstract}
Due to the global increase in temperature, heat stress has become a great threat for the crops production worldwide. This research was conducted to assess the genotypic variability and relationship of accumulation of glycine betaine, proline, chlorophyll contents, and cell membrane thermostability with yield in different cauliflower varieties under heat stress. Heat stress was imposed by early sowing of genotypes (in July as compared to September sowing). Under the early sown condition, the high temperature was experienced by the plants during the curd development stage. Heat tolerance ability of the genotypes was assessed by their ability to curd induction and development at high temperature and also based on different physiological traits. Heat susceptible genotypes showed lengthened curd induction stage. Further, decrease in chlorophyll and osmoprotectants contents was also seen in heat susceptible genotypes. TSX-C40 was identified as most susceptible genotype to heat stress due to low accumulation of glycine betaine and proline, and greater relative cell injury percentage, along with lengthened curd induction stage. Curd induction in TSX-C40 was seen when the maximum temperature was between $21.5-26.0{ }^{\circ} \mathrm{C}$. While $\mathrm{CF}$-Early was identified as heat tolerant genotype as curd induction was started at an average maximum temperature of $34^{\circ} \mathrm{C}$. Further $\mathrm{CF}-$ Early showed high chlorophyll contents, and more glycine betaine, and proline accumulation. Less relative cell injury percentage resulted in less damage to cell membranes and the protection of the photosynthetic apparatus during the heat stress of CF-Early. In addition, the accumulation of more osmoprotectants in $\mathrm{CF}$ Early may lead to reactive oxygen species scavenging to protect cell membranes.

Received | October 22, 2020; Accepted | March 18, 2021; Published | June 20, 2021

*Correspondence | Saba Aleem, Barani Agricultural Research Station, Fatehjang, Pakistan; Email: sabaaleem22@gmail.com

Citation $\mid$ Aleem, S., I. Sharif, M. Tahir, M. Najeebullah, A. Nawaz, M.I. Khan, A. Batool and W. Arshad. 2021. Impact of heat stress on cauliflower (Brassica Oleracea var. Botrytis): A physiological assessment. Pakistan Journal of Agricultural Research, 34(3): 479-486.

DOI | https://dx.doi.org/10.17582/journal.pjar/2021/34.3.479.486

Keywords | Heat stress, Cell membrane thermostability, Relative cell injury percentage, Glycine betaine, Proline
\end{abstract}

\section{Introduction}

Since the last century, an increase in global air Stemperature has been recorded due to the anthropogenic activities of humans. From 1880 to 2012, a rise of 1 to $2{ }^{\circ} \mathrm{C}$ in global air temperature has been observed. By the end of this century, a $3-5{ }^{\circ} \mathrm{C}$ increase has been expected (IPCC, 2007, 2012). As crop growth and development is highly linked with the temperature so this rise in temperature created an alarming situation for future crop production (Rasul et al., 2011).

Cauliflower is a cool-season crop and temperature plays a critical role in curd induction. As on the basis of temperature requirement they are classified into early, mid and late season groups. However, most of the genotypes require an optimum temperature of 20-25 
${ }^{\circ} \mathrm{C}$ for curd induction (Singh et al., 2018). Continuous availability of more than $30^{\circ} \mathrm{C}$ temperature conditions for 10 days caused a $10 \%$ yield reduction in cauliflower and cabbage genotypes (Warland et al., 2006). Future climate model-based studies also prophesied a drastic impact of increasing temperature on cauliflower cultivation. Wurr et al. (2004) projected the climate change implications for cauliflower production in 2020, 2050, and 2080. Through this study it was identified that both juvenal and curd growth stage would be shortened while the curd induction stage would be lengthened with the rising temperature in the future. Findings of (Warland et al., 2006; Wurr et al., 2004 \#20) are creating challenging conditions for cauliflower cultivations shortly.

Heat stress (HS) reduces the photosynthesis by damaging the photosynthesis machinery. Decrease in photosynthesis in response to heat stress has been recorded in several crops. Heat stress also cause excessive accumulation of the reactive oxygen species (ROS) which target the lipids, proteins, and polysaccharides. ROS accumulation results in the oxidative stress that increases the membrane peroxidation and severely damages the membranes (Belhadj et al., 2014; Martinez et al., 2018; Petrov et al., 2015). These damages alter the permeability of the membranes and resulted in leakage of solute (electrolytes). As electrolyte leakage reflects cellular membranes damage, hence the measurement of electrolytes has been commonly used to measure cell membrane thermostability (CMT). CMT has been used as a criterion in variety of crops to assess their heat tolerance ability e.g. pepper, tomato, wheat, and cotton (Golam et al., 2012; Hasan et al., 2007; Rahman et al., 2004; Usman et al., 2014).

HS tolerance is a complicated phenomenon that involves a range of physiological and biochemical pathways. Osmoprotectants accumulation such as proline, polyamines, carotenoids, tocopherols, ascorbic acid, and glycine betaine is also one of these physiological responses that give protection against heat stress. As accumulation of osmoprotectants leads to osmotic adjustment in cell and helps the cell in scavenging ROS and also provide protection to enzymes and biological membranes (Gill and Tuteja, 2010). Exogenous treatment of proline and glycine betaine was also found effective in minimizing $\mathrm{H}_{2} \mathrm{O}_{2}$ production, enhancing soluble sugar aggregation, and protecting the growing tissues against heat stress
(Rasheed et al., 2011). In comparison to glycine betaine, proline was shown to be more effective in reducing effect of heat stress (Kaushal et al., 2011).

In cauliflower genotypes have been identified that can develop curd at high temperature but the mechanism of heat tolerance of these varieties is not clear. So, understanding of the physiological mechanisms may provide comprehensive details for the selection and development of heat tolerant cultivars of cauliflower. The present research was designed to assess inbuilt heat tolerance ability of different cauliflower genotypes based on physiological traits. CMT and other physiological traits such as chlorophyll, proline, and glycine betaine contents were used as criteria to evaluate heat tolerance in cauliflower genotypes. Heat tolerance ability of the genotypes was also assessed by their ability of curd induction to curd development at high temperature. Further, for a comprehensive understanding of heat tolerance mechanism in cauliflower, relationship was checked between physiological parameters and yield.

\section{Materials and Methods}

The present trial was conducted in the farm area of the Vegetable Research Institute, Ayub Agricultural Research Institute, Faisalabad in 2019. A total of eight genotypes including six elite (HCF-151A, HCF900A, HCF-910A, HCF-911A, Sohni, TSX-C40) and two locals (CF-early and FD_II) were used in this study. Both the local genotypes were collected from the germplasm material which were developed after the three cycles of recurrent selection at a Vegetable Research Institute. While elite genotypes were collected from private companies who are importing these genotypes from foreign countries. For assessing the heat tolerance ability, the nursery of the genotypes was sown in July 2019 so that genotypes would expose to high temperature at the time of curd formation. During $1^{\text {st }}$ week of August nursery was transplanted in three replications following randomized complete block design keeping plot size of $5 \times 0.75$ square meters. The seedlings were transplanted on a single side of the rows keeping plant to plant distance of 45 $\mathrm{cm}$. Middle five plants were taken for collecting data of all the parameters to minimize the border effect. For evaluating the genotype ability to develop curd at high temperature, days from the sowing to curd induction also noted. Maximum day temperature was also recorded on daily basis. However, yield per plot is 
used for estimating yield in tonnes per hectare $(\mathrm{t} / \mathrm{ha})$. Throughout the crop season, all the plant protection measures, and agronomic practices were carried out to avoid the effect of other biotic and abiotic stresses. Heat tolerance in relation to cell membrane thermostability in the experimental material was measured after exposure of the genotypes with heat stress by using relative cell injury percentage (RCI $\%)$ as described (Sullivan, 1972). In addition to cell membrane thermostability, other physiological parameters such as proline contents (mole/g), glycine betaine $(\mathrm{mole} / \mathrm{g})$, chlorophyll $\left(\mu \mathrm{mole} / \mathrm{m}^{2}\right)$, and yield ( $t / h a)$ of the genotype were also measured to assess the heat tolerance. The measurement of these physiological parameters was recorded on $4^{\text {th }}$ October 2019 during 13:00 to 15:00 hour, at average air temperature of $34.5{ }^{\circ} \mathrm{C}$. The maximum temperature faced by the crop during different growth stages is presented in the Figure 1.

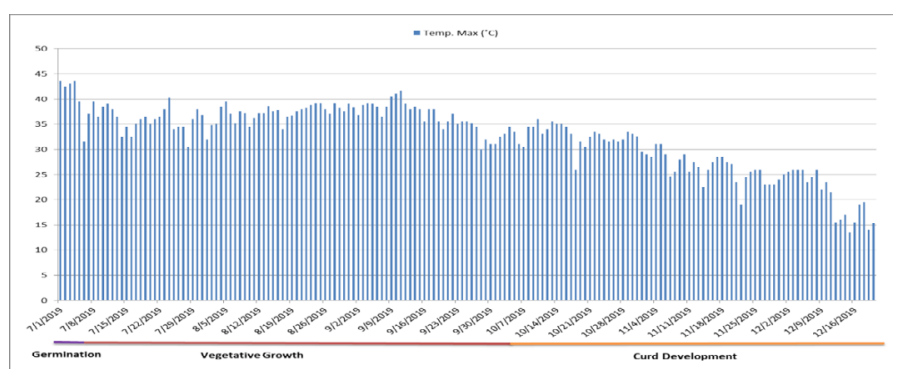

Figure 1: Maximum temperature faced by cauliflower genotypes during different growth stages.

\section{Estimation of chlorophyll contents}

The chlorophyll contents were estimated as previously described by (Arnon, 1949). Almost $1 \mathrm{~g}$ of leaf sample was chopped into little pieces and then added $80 \%$ $\mathrm{v} / \mathrm{v}$ of acetone to homogenize the leaf tissue. While grinding the leaf tissue, a pinch of calcium carbonate was also added. After this, the centrifugation of extract was done at $3000 \mathrm{rpm}$ for $15 \mathrm{~min}$. Later on, 80\% (v/v) acetone was added in extract for making its final volume to $25 \mathrm{ml}$. The clear solution was extracted in a colorimeter tube and by using UV spectrophotometer its OD was measured at $645 \mathrm{~nm}$ and also at $663 \mathrm{~nm}$ wavelength, against an $80 \%$ blank acetone solution. The total chlorophyll contents were measured as $\mu \mathrm{mol} / \mathrm{g}$ of fresh weight of the leaf.

\section{Measurement of CMT}

CMT was measured using the method previously proposed by (Sullivan, 1972). As leaves of different ages might show variable response, the youngest leaves of all the genotypes during the first week of October were used for measuring CMT. Samples of the leaves were collected from both sides of the leaf midrib. A microfuge tube cape was used as a puncher for punching the leaf discs. Four discs from each side of the leaf midrib were used for each treatment (control and heat treatment). Two sample sets were prepared for the experiment and one for heat treatment and other for control. In the laboratory, leaf discs were rinsed gently with de-ionized water to wipe out adherent and already released electrolytes. Samples were washed thrice. After washing, $2 \mathrm{ml}$ of water was added in each test tube. Upper side of the test tubes were covered with aluminum foil and sealed tightly to prevent desiccation and evaporation of water. Heat treatment labeled test tubes set was kept in the water bath for $1 \mathrm{~h}$ that was already maintained at $50{ }^{\circ} \mathrm{C}$. The controlled set of test tubes was placed at $25{ }^{\circ} \mathrm{C}$ for $1 \mathrm{~h}$. Almost after $1 \mathrm{~h}$ test tubes were extracted from the water bath and $10 \mathrm{ml}$ water was added in all the treated and controlled vials and placed both sets of vials at temperature $10{ }^{\circ} \mathrm{C}$ for $24 \mathrm{~h}$ for complete diffusion of electrolytes. Then both sets of vials were cooled to $25{ }^{\circ} \mathrm{C}$ and shaken gently. Initial electrical conductivity (EC) was recorded by using EC-meter (SN-F0005599, Hanna Instruments, USA). After this, test tubes were placed in the autoclave at 0.10 $\mathrm{MPa}$ pressure for $10 \mathrm{~min}$. After cooling down to $25{ }^{\circ} \mathrm{C}$ and the final EC of both test tubes sets was recorded. Relative cell injury percentage (RCI\%) was calculated by the following formula.

$$
\mathrm{RCI}(\%)=1-\frac{1-\left(\frac{\mathrm{T} 1}{\mathrm{~T} 2}\right)}{1-\left(\frac{\mathrm{C} 1}{\mathrm{C} 2}\right)} \times 100
$$

Here "T" describes EC of heat-treated and "C" describes the $\mathrm{EC}$ of controlled test tubes and number 1 shows the first EC measured before autoclave and number 2 shows the final EC measured after autoclave.

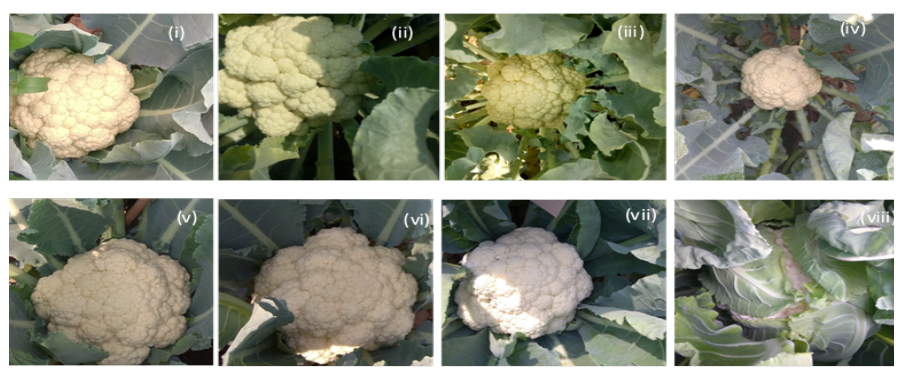

Figure 2: Curd of different studied cauliflower varieties; (i) CFEarly, (ii) FD-II, (iii) $H C F-151 A$, (iv) $H C F-900 A$, (v) $H C F-$ 910A, (vi) HCF-911A, (vii) Sohni, (viii) TSX-C40. 
Estimation of glycine betaine

For the glycine betaine estimation, fully expanded uppermost leaves were taken from all the heat stress genotypes and GB was measured as described by (Grieve and Grattan, 1983). Leaf sample of $0.5 \mathrm{~g}$ was chopped by adding $5 \mathrm{ml}$ of toluene water in test tubes. All the test tubes were placed in a shaker and shaken at $25{ }^{\circ} \mathrm{C}$ for $24 \mathrm{~h}$. Then $0.5 \mathrm{ml}$ of extract was gently mixed with $1 \mathrm{ml}$ of $2 \mathrm{~N} \mathrm{HCl}$ solution. Later on, $0.1 \mathrm{ml}$ potassium tri-iodide solution containing $10 \mathrm{~g}$ potassium iodide (KI) and $7.5 \mathrm{~g}$ iodine (I) in $100 \mathrm{~mL}$ of $1 \mathrm{NHydrochloric} \mathrm{acid}(\mathrm{HCl})$ was added and shaken the mixture in ice-cold shaker for $90 \mathrm{~min}$. After this 2 $\mathrm{ml}$ of cooled water was added to the solution and then $10 \mathrm{~mL}$ of chilled 1,2 dichloroethane $\left(\mathrm{C}_{2} \mathrm{H}_{4} \mathrm{Cl}_{2}\right)$ was added into it. Bypassing a continuous air stream for 2 minutes, the solution was separated into two layers; one was aqueous and second was organic layer. The aqueous layer present on top was discarded and the OD of organic layer was taken at wavelength of 365 $\mathrm{nm}$. Glycine betaine contents was measured using a standard curve.

\section{Estimation of proline contents}

Proline contents were estimated as previously reported by (Bates et al., 1973). Firstly, took $0.5 \mathrm{~g}$ leaf tissue and fine homogenized mixture of the leaf was prepared in $10 \mathrm{ml}$ of $3 \%$ sulfosalicylic acid. Then homogenized mixture was filtered through filter paper. Then $2 \mathrm{ml}$ volume of the filtrate was taken and added in $2 \mathrm{ml}$ of acid ninhydrin solution which was made by mixing $1.25 \mathrm{ml} \mathrm{2,2-dihydroxyindane} \mathrm{-1,3-dione} \mathrm{in} 20 \mathrm{ml}$ of orthophosphoric acid (6 M) and glacial acetic acid. Then heated the mixture at $100{ }^{\circ} \mathrm{C}$ for 1 hour and cooled the mixture at room temperature. From the mixture liquid was extracted by adding $10 \mathrm{ml}$ of toluene and absorbance at $520 \mathrm{~nm}$ was read using toluene as blank.
Statistical analysis

The data of all the traits was analyzed byusing analysis of variance techniques and further mean comparison was done by LSD using Statistix 8.1 software. Regression analysis between yield and other physiological traits was also carried out to find the relation between yield and morpho-physiological traits.

\section{Results and Discussion}

\section{Effect of heat stress on curd induction and curd development}

Curd induction stage was found highly associated with temperature in cauliflower. In some of the genotypes, curd induction was started in October when the maximum temperature during the day time has remained more than $30{ }^{\circ} \mathrm{C}$. Genotypes such as CF-early, Sohni, and FD-II were able to start curd when maximum temperature was more than $30{ }^{\circ} \mathrm{C}$ (Table 1). Curd induction was started earlier in $\mathrm{CF}$ early almost 85 days after sowing and took almost 10 to15 days to form complete curd from the date of curd induction. FD-II and Sohni were also started earlier curd induction. In these varieties, curd induction was started almost after 100 days of sowing and took almost 10 days to complete the curd formation from the date of curd induction. CF-Early developed the marketable size curd with the compact growth and white color. Further, no raciness was seen on the curd of CF-Early while raciness was seen on FD-II curd. In other genotypes, curd induction was not started until the temperature reached below $30^{\circ} \mathrm{C}$. Curd induction was lengthened too much in TSX-C40 as curd induction was started after 120-125 days of sowing and took almost 140 to 155 days for curd development from the date of the sowing in Table 1. In HCF-151A, HCF-900A, HCF-910A and HCF911B genotype curd induction was also delayed.

Table 1: Relationship of curd development with temperature.

\begin{tabular}{|c|c|c|c|c|}
\hline Genotypes & $\begin{array}{l}\text { Curd induction start after } \\
\text { the date of sowing (Days) }\end{array}$ & $\begin{array}{l}\text { Curd development after } \\
\text { the date of sowing (Days) }\end{array}$ & $\begin{array}{l}\text { Max. temperature }{ }^{\circ} \mathrm{C} \text { faced } \\
\text { during curd development }\end{array}$ & $\begin{array}{l}\text { Average temperature }{ }^{\circ} \mathrm{C} \text { faced } \\
\text { during curd development }\end{array}$ \\
\hline CF- Early & $85-100$ & $95-110$ & $30.5-36$ & 34 \\
\hline FD-II & $90-100$ & $100-110$ & $31.5-33.5$ & 32 \\
\hline HCF-151A & $105-120$ & $115-130$ & $24.6-31$ & 29 \\
\hline HCF-900A & $105-115$ & $115-125$ & $24.6-31$ & 28 \\
\hline HCF-910A & $105-115$ & $115-125$ & $24.6-31$ & 27 \\
\hline HCF-911B & $120-130$ & $125-135$ & $24.6-31$ & 27 \\
\hline Sohni & $90-100$ & $100-110$ & $31.5-33.5$ & 32 \\
\hline TSX-C40 & $120-125$ & $140-155$ & $21.5-26$ & 24 \\
\hline
\end{tabular}

September 2021 | Volume 34 | Issue 3 | Page 482 
Curd developed by different varieties has been highlighted in Figure 2.

\section{Effect of heat stress on physiological traits}

Under July sown crop, high temperature coincides with the crop from its germination stage to curd development. During germination, genotypes faced a temperature of $43{ }^{\circ} \mathrm{C}$ while during the vegetative growth maximum temperature of $30-41.6{ }^{\circ} \mathrm{C}$ was recorded presented in (Figure 1). Analysis of variance showed significant variation among the studied genotypes regarding physiological parameters under heat stress (Table 1). Based on the mean comparison, all the genotypes were divided into distinct groups.

Genotypes showed significant differences regarding glycine betaine contents presented in Table 2 . Mean comparison based on LSD showed that there are three significantly different groups. CF-early showed the maximum value for the glycine betaine (30.79 mole/g) while genotype TSX-C40 showed a minimum value $(20.34 \mathrm{~mole} / \mathrm{g})$ while in the rest of the genotypes glycine betaine contents were varied from 20.88 to $26.02 \mathrm{~mole} / \mathrm{g}$ (Table 3).

Table 2: Mean squares for various morpho-physiological traits related to heat tolerance.

\begin{tabular}{llll} 
Traits & \multicolumn{3}{c}{ Mean squares } \\
& $\begin{array}{l}\text { Replication } \\
(\mathbf{d f}=2)\end{array}$ & $\begin{array}{l}\text { Genotypes } \\
(\mathbf{d f}=7)\end{array}$ & $\begin{array}{l}\text { Error } \\
(\mathbf{d f}=14)\end{array}$ \\
Chlorophyll & 0.640 & $17.782^{* *}$ & 0.687 \\
Glycine betaine & 2.535 & $38.980^{* *}$ & 0.818 \\
Proline & 0.814 & $6.402^{* *}$ & 0.720 \\
RCI\% & 6.383 & $251.740^{* *}$ & 4.625 \\
Yield & 0.707 & $249.984^{* *}$ & 15.946
\end{tabular}

*: significant at $P<0.05$, *** bighly significant $P<0.01$.

A significant difference has been recorded in proline contents of studied genotype under heat stress (Table 2). Four distinct groups have been identified based on the mean comparison of proline by LSD. Presently studied genotypes had proline contents varying from 15.96 to $10.92 \mathrm{~mol} / \mathrm{g}$. The highest proline contents were recorded in CF-early $(15.96 \mathrm{~mol} / \mathrm{g})$ and the lowest proline contents $(10.92 \mathrm{~mol} / \mathrm{g})$ were recorded in HCF-151A (Table 3).

A significant difference has been recorded in chlorophyll contents of studied genotype under heat stress (Table 2). Four distinct groups have been identified based on the mean comparison of proline by LSD. Presently studied genotypes had chlorophyll contents varying from 5.92 to $11.96 \mu$ mole $/ \mathrm{m}^{2}$ (Table $3)$. The highest value of chlorophyll contents was recorded in the CF-early genotype while the lowest value was recorded in TSX-C40 genotypes (Table 3).

$\mathrm{RCI} \%$ represents the cell membrane thermostability, more the RCI \% less would be the cell membrane thermostability. Overall, more than $70 \%$ RCI was recorded in all the genotypes which indicated that all the genotypes are sensitive to heat stress. A comparison of genotype means for $\mathrm{RCI} \%$ showed that the genotype HCF-151A had the highest value 98.03 and genotype CF-Early had a minimum value (73.60). While the remaining genotypes have RCI \% values varying from 81.90 to 97.93 (Table 3).

Table 3: Comparison of different genotypes for various physiological traits related to heat tolerance.

$\begin{array}{llllll}\text { Genotypes } & \begin{array}{l}\text { Chlorophyll } \\ \text { contents } \\ \left(\mu \mathrm{mole} / \mathbf{m}^{2}\right)\end{array} & \begin{array}{l}\text { Glycine } \\ \text { betaine } \\ \text { mole/g) }\end{array} & \begin{array}{l}\text { Proline } \\ (\mathbf{m o l e} / \mathbf{g})\end{array} & \text { RCI\% } & \text { Yield } \\ \text { CF-Early } & 11.96 \mathrm{a} & 30.79 \mathrm{a} & 15.96 \mathrm{a} & 73.60 \mathrm{~d} & 31.17 \mathrm{~b} \\ \text { FD-II } & 11.72 \mathrm{a} & 21.08 \mathrm{c} & 13.56 \mathrm{c} & 81.90 \mathrm{c} & 19.10 \mathrm{~cd} \\ \text { HCF-151A } & 8.17 \mathrm{bc} & 21.46 \mathrm{c} & 10.92 \mathrm{~d} & 98.03 \mathrm{a} & 13.27 \mathrm{~d} \\ \text { HCF-900A } & 6.80 \mathrm{~cd} & 20.88 \mathrm{c} & 13.55 \mathrm{bc} & 97.00 \mathrm{a} & 17.38 \mathrm{~cd} \\ \text { HCF-910A } & 7.52 \mathrm{bc} & 21.86 \mathrm{c} & 13.17 \mathrm{c} & 97.93 \mathrm{a} & 30.26 \mathrm{~b} \\ \text { HCF-911A } & 8.43 \mathrm{~b} & 21.49 \mathrm{c} & 13.45 \mathrm{bc} & 95.80 \mathrm{ab} & 18.93 \mathrm{~cd} \\ \text { Sohni } & 11.79 \mathrm{a} & 26.02 \mathrm{c} & 14.88 \mathrm{ab} & 93.60 \mathrm{~b} & 21.03 \mathrm{c} \\ \text { TSX-C40 } & 5.92 \mathrm{~d} & 20.34 \mathrm{~b} & 13.18 \mathrm{c} & 97.76 \mathrm{a} & 40.59 \mathrm{a} \\ \text { Average } & 9.04 & 22.99 & 13.53 & 91.95 & 23.9 \\ \text { LSD } & 1.45 & 1.58 & 1.49 & 3.76 & 6.91\end{array}$

Genotypic means sharing a similar letter for a trait in a column are statistically non-significant $(P>0.05)$.

\section{Regression analysis}

To find the relationship between different physiological parameters and yield under heat stress regression analysis was used. The relationship between relative cell injury percentage and yield during heat stress was studied through regression analysis(Figure 4). Regression analysis represented a linear negative relationship between RCI \% and yield during heat stress which described a strong evidence that RCI \% is negatively corelated with yield while CMT and yield are positively corelated to each other. As a decrease in RCI \% would increase the CMT and improves the heat tolerance ability of the genotype (Figure 3). A positive linear relationship was also observed of yield with glycine betaine and proline contents during heat stress conditions. 


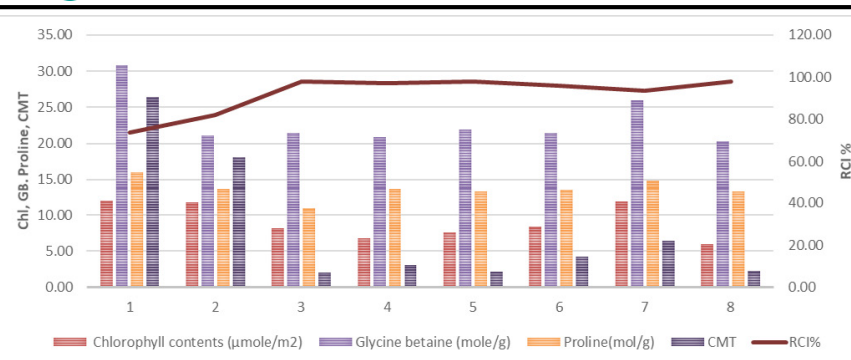

Figure 3: Relationship of RCI \% with different other physiological parameters.

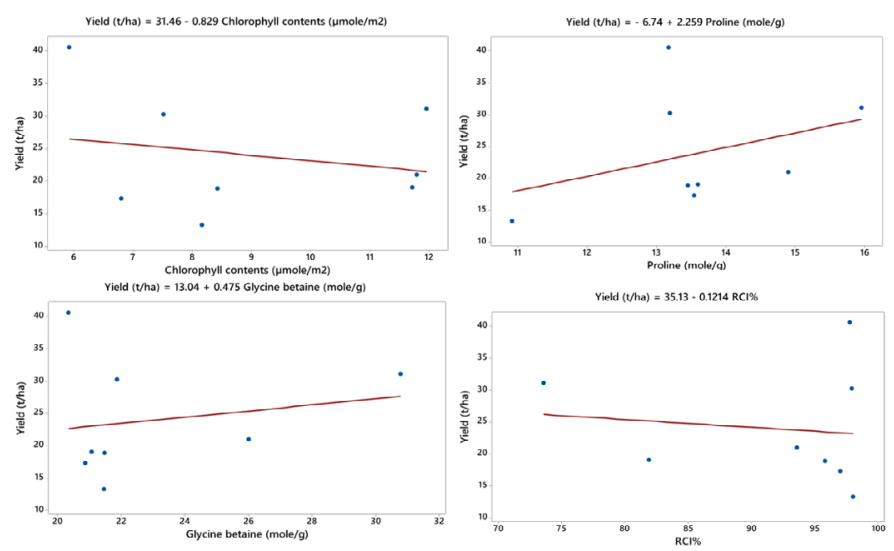

Figure 4: Regression analysis between the yield and different physiological traits under heat stress.

Heat tolerance describes as the ability of a genotype not only to grow but also produce an economical yield in heat stress. In response to heat stress, various morphological changes occur in plants that provide reasons for the reduction in yield (Fahad et al., 2017). The negative effect of heat stress on the yield of cool-season brassica was previously reported i.e. in cauliflower, $10 \%$ yield losses for every 10 days were recorded when the temperature exceeds $30{ }^{\circ} \mathrm{C}$ (Warland et al., 2006). In this study, curd induction at $>30{ }^{\circ} \mathrm{C}$ was started in three genotypes. Out of these three, genotype $\mathrm{CF}$-early was able to develop marketable curd with good curd shape, color, and size when the maximum average temperature was $34{ }^{\circ} \mathrm{C}$. So, this genotype is characterized as heat tolerant while the rest of the genotypes did not develop the curd at this temperature. For rest of the genotypes, curd induction was lengthened due to warmer conditions during vegetative growth and they took 105-125 days for curd induction. In genotype TSX-C40 curd induction took 120 to 125 days from the date of sowing and it developed the marketable curd when the average maximum temperature was $24^{\circ} \mathrm{C}$. Hence genotype TSX-C40 characterized as heat susceptible and was not found effective for July sowing. Delay in curd induction due to warmer conditions in coolseason brassica crops especially cauliflower was also reported by (Warland et al., 2006).

All the morphological changes at the vegetative and reproductive growth stages due to heat stress are the outcomes of a disturbance in cellular processes at the physiological and biochemicallevels. At the subcellular level, the photosynthesis process is very sensitive to heat stress. High temperature reduced photosynthetic activity of the heat susceptible genotypes due to reduction in photosynthesis pigments i.e. chlorophylls and carotenoids (Hasanuzzaman et al., 2013; Sharkey and Zhang, 2010). In the present study reduction in chlorophyll contents of the heat susceptible genotypes was recorded. Genotype TSX-C40 was not able to form curd at high temperature showed minimum chlorophyll contents. Chlorophyll contents of heat susceptible genotype were reduced up to $50 \%$ during heat stress conditions. The regression line also indicated that during heat stress increase in chlorophyll contents would increase the yielding ability of the genotype by improving photosynthesis efficiency. Similarly, a decrease in net photosynthetic rate was recorded in tomato plants subjected to $38^{\circ} \mathrm{C}$ (Cheng et al., 2009).

Heat stress triggers the aggregation of different organic and inorganic osmolytes that serve as ROS scavengers. An increase in endogenous contents of these osmolytes is seen in heat tolerant genotypes while heat-sensitive plants don't show this ability. In the present study heat tolerant genotype $\mathrm{CF}$ early showed 35\% more glycine betaine and 31\% more proline contents than susceptible genotypes respectively. The present results are consistent with the finding of (Kaushal et al., 2011) who reported a 3.4 fold increase in proline contents of heat tolerant chickpea genotypes at $40 / 35^{\circ} \mathrm{C}$. Similarly, in sugarcane, glycine betaine and proline were found to be effective in restricting the $\mathrm{H}_{2} \mathrm{O}_{2}$ production and improving the $\mathrm{K}^{+}$and $\mathrm{Ca}^{+2}$ contents and heat tolerance of the sprouting buds (Rasheed et al., 2011).

Cell membrane stability is another important physiological parameter that is disturbed by heat stress. When the cell membrane is exposed to heat stress, it is severely injured, and its permeability is increased resulting in electrolyte diffusion outside of the cell that could be determined by RCI\%. The low value of $\mathrm{RCI} \%$ shows high CMT and the high value of RCI \% reflects low CMT. RCI \% in the studied genotypes showed a significant difference. Two 
genotypes CF-Early and FD-II show below-average RCI \%. While in the rest of the genotypes, RCI \% was recorded as more than $91.95 \%$. In high yielding genotype (TSX-C40) the value of $\mathrm{RCI} \%$ was also greater than average (97.76\%) which indicated that the genotype is highly susceptible to heat stress. From the study, it was seen that genotypes with more glycine betaine and proline accumulation have less relative cell injury percentages such as CF-Early. While genotypes with more $\mathrm{RCI} \%$ showed less proline and glycine betaine contents such as HCF-151A and TSX-C40. (Rahman et al., 2004) reported similar findings in cotton when used $\mathrm{RCI} \%$ as a criterion to evaluate different hybrid and varieties regarding heat tolerance at the flowering stage. In stressed condition significant negative relationship of $\mathrm{RCI} \%$ was seen with seed cotton yield Similarly in sugarcane, CMT was used as an indicator of heat tolerance and found helpful in improving selection efficiency regarding high-temperature stress (Nava and Rubio, 2019).

\section{Conclusions and Recommendations}

Due to heat stress, early planting significantly reduced the glycine betaine, proline, and chlorophyll contents of heat susceptible genotypes. Further, it was identified only heat tolerant genotypes were able to develop curd at high temperature while heat susceptible genotypes not able to develop curd at high temperature. Susceptible genotypes were found to be late maturing and continue their vegetative growth and develop the head when the temperature falls below $30^{\circ} \mathrm{C}$. Based on curd induction and curd development at high temperature and $\mathrm{RCI} \%$, three genotypes CF-early, FD-II, and Sohni were found to be heat tolerant. Identified tolerant genotypes would be utilized for understanding the physiological basis of heat tolerance and of course for the cauliflower yield improvement program under heat stress.

\section{Novelty Statement}

Information regarding the Impact of Heat Stress on Cauliflower has been presented in the paper which were not previously studied

\section{Author's Contribution}

Saba Aleem: Conceived the idea, wrote abstract, methodology, did statistics analysis and wrote Conclusion.
Iram Sharif: Collected data, helped in writing introduction, result, discussion and references.

Mehvish Tahir: Collected data, helped in writing introduction and references.

Muhammad Najeebullah and Ali Nawaz: Technical Input at every step.

Muhammad Imran Khan and Waheed Arshad: Overall management of the article.

Amina Batool: Helped in writing result and discussion, introduction and references.

\section{Conflict of interest}

The authors have declared no conflict of interest.

\section{References}

Arnon, D.I., 1949. Copper enzymes in isolated chloroplasts. Polyphenoloxidase in Beta vulgaris. Plant Physiol., 24: 1. https://doi.org/10.1104/ pp.24.1.1

Bates, L.S., R.P. Waldren and I. Teare. 1973. Rapid determination of free proline for water-stress studies. Plant Soil, 39: 205-207. https://doi. org/10.1007/BF00018060

Belhadj, S.I., T. Najar, A. Ghram, H. Dabbebi, M. Ben Mrad and M. Abdrabbah. 2014. Reactive oxygen species, heat stress and oxidativeinduced mitochondrial damage. A review. Int. J. Hyperth., 30: 513-523. https://doi.org/10.3109 /02656736.2014.971446

Cheng, L., Y. Zou, S. Ding, J. Zhang, X. Yu, J. Cao and G. Lu. 2009. Polyamine accumulation in transgenic tomato enhances the tolerance to high temperature stress. J. Integr. Plant Biol., 51: 489-499. https://doi.org/10.1111/j.17447909.2009.00816.x

Fahad, S., A.A. Bajwa, U. Nazir, S.A. Anjum, A. Farooq, A. Zohaib, S. Sadia, W. Nasim, S. Adkins and S. Saud. 2017. Crop production under drought and heat stress: plant responses and management options. Front. Plant Sci., 8: 1147. https://doi.org/10.3389/fpls.2017.01147

Gill, S.S. and N. Tuteja. 2010. Reactive oxygen species and antioxidant machinery in abiotic stress tolerance in crop plants. Plant Physiol. Biochem., 48: 909-930. https://doi. org/10.1016/j.plaphy.2010.08.016

Golam, F., Z.H. Prodhan, A. Nezhadahmadi and M. Rahman. 2012. Heat tolerance in tomato. Life Sci. J., 9: 1936-1950.

Grieve, C. and S. Grattan. 1983. Rapid assay for determination of water soluble quaternary

September 2021 | Volume 34 | Issue 3 | Page 485 
ammonium compounds. Plant Soil, 70: 303307. https://doi.org/10.1007/BF02374789

Hasan, M.,J. Ahmed, M. Bahadur, M. Haque and S. Sikder. 2007. Effect of late planting heat stress on membrane thermostability, proline content and heat susceptibility index of different wheat cultivars. J. Natl. Sci. Found. Sri Lanka, pp. 35. https://doi.org/10.4038/jnsfsr.v35i2.3675

Hasanuzzaman, M., K. Nahar, M. Alam, R. Roychowdhury and M. Fujita. 2013. Physiological, biochemical, and molecular mechanisms of heat stress tolerance in plants. Int. J. Mol. Sci., 14: 9643-9684. https://doi. org/10.3390/ijms14059643

IPCC, 2007. The Physical Science Basis. Cambridge, United Kingdom and New York, NY, USA., Cambridge University Press.

IPCC, 2012. Managing the risks of extreme events and disasters to advance climate change adaptation. Cambridge University, United Kingdom and New York, NY,USA., Cambridge University Press.

Kaushal, N., K. Gupta, K. Bhandhari, S. Kumar, P. Thakur and H. Nayyar. 2011. Proline induces heat tolerance in chickpea (Cicer arietinum L.) plants by protecting vital enzymes of carbon and antioxidative metabolism. Physiol. Mol. Biol. Plants, 17: 203. https://doi.org/10.1007/ s12298-011-0078-2

Martinez, V., M. Nieves-Cordones, M. LopezDelacalle, R. Rodenas, T. Mestre, F. GarciaSanchez, F. Rubio, P. Nortes, R. Mittler and R. Rivero. 2018. Tolerance to stress combination in tomato plants: New insights in the protective role of melatonin. Molecular, 23: 535. https:// doi.org/10.3390/molecules23030535

Nava, C.S. and L.E. Rubio. 2019. Thermotolerance and physiological traits as fast tools to heat tolerance selection in experimental sugarcane genotypes. Agriculture, 9: 251. https://doi. org/10.3390/agriculture9120251

Petrov, V., J. Hille, B. Mueller-Roeber and T.S. Gechev. 2015. ROS-mediated abiotic stressinduced programmed https://doi.org/10.3389/ fpls.2015.00069 cell death in plants. Front Plant Sci., 6: 69.
Rahman, H.u., S.A. Malik and M. Saleem. 2004. Heat tolerance of upland cotton during the fruiting stage evaluated using cellular membrane thermostability. Field Crops Res., 85: 149-158 https://doi.org/10.1016/S03784290(03)00159-X.

Rasheed, R., A. Wahid, M. Farooq, I. Hussain and S.M. Basra. 2011. Role of proline and glycinebetaine pretreatments in improving heat tolerance of sprouting sugarcane (Saccharum sp.) buds. Plant Growth Regul., 65: 35-45. https://doi.org/10.1007/s10725-011-9572-3

Rasul, G., Q. Chaudhry, A. Mahmood and K. Hyder. 2011. Effect of temperature rise on crop growth and productivity. Pak. J. Meteorol., 8: 53-62.

Sharkey, T.D. and R. Zhang. 2010. High temperature effects on electron and proton circuits of photosynthesis. J. Integ. Plant Biol., 52: 712-722. https://doi.org/10.1111/j.17447909.2010.00975.x

Singh, B., B. Singh, and P. Singh. 2018. Breeding cauliflower: A review. Int. J. Veg. Sci., 24: 5884. https://doi.org/10.1080/19315260.2017.13 54242

Sullivan, C.Y., 1972. Mechanisms of heat and drought resistance in grain sorghum and methods of measurement. Sorghum in Seventies. Oxford \& IBH Pub. Co.

Usman, M.G., M. Rafii, M. Ismail, M. Malek and M. Abdul Latif. 2014. Heritability and genetic advance among chili pepper genotypes for heat tolerance and morphophysiological characteristics. Sci. World J., 2014. https://doi. org $/ 10.1155 / 2014 / 308042$

Warland,J., A.W.McKeown and M.R.McDonald. 2006. Impact of high air temperatures on Brassicacae crops in southern Ontario. Can. J. Plant Sci., 86: 1209-1215. https://doi. org/10.4141/P05-067

Wurr, D., J.R. Fellows and M. Fuller. 2004. Simulated effects of climate change on the production pattern of winter cauliflower in the UK. Sci. Hortic., 101: 359-372. https://doi. org/10.1016/j.scienta.2003.11.011 